\title{
Molecular genetic confirmation of the subspecies status of blues Agriades orbitulus pheretimus (Staudinger, 1892) and A. orbitulus jugnei Churkin, 2004 (Lepidoptera: Lycaenidae: Polyommatinae)
}

\section{Молекумярно-генетическое подтверждение подвидового статуса голубянок Agriades orbitulus pheretimus (Staudinger, 1892) и A. orbitulus jugnei Churkin, 2004 (Lepidoptera: Lycaenidae: Polyommatinae)}

\author{
B.V. Stradomsky ${ }^{1}$, R.V. Yakovlev ${ }^{2,3}$, E.S. Fomina ${ }^{4}$ \\ Б.В. Страдомскийㅁ, Р.В. Яковлев ${ }^{2,3}$, Е.С. Фомина ${ }^{4}$
}

\footnotetext{
Rostov branch of Russian Entomological Society, PO Box 3318, 344092 Rostov-na-Donu, Russia. E-mail: bvstr@yandex.ru

2 Altai State University, Prospect Lenina 61, 656049 Barnaul, Russia. E-mail: yakovlev_asu@mail.ru

${ }^{3}$ Tomsk State University, Prospect Lenina, 36, 634050 Tomsk, Russia.

${ }^{4}$ Southern Scientific Centre of the Russian Academy of Sciences, Chekhov str. 41, Rostov-on-Don 344006, Russia.

${ }^{1}$ Ростовское отделение Русского энтомологического общества, а/я 3318, 344092 Ростов-на-Дону, Россия.

2 Алтайский государственный университет, пр. Ленина 61, Барнаул 656049, Россия.

3 Томский государственный университет, пр. Ленина 36, Томск 634050, Россия.

${ }^{4}$ Южный научный центр РАН, пр. Чехова 41, Ростов-на-Дону 344006, Россия
}

KEY WORDS: fauna, COI, ITS2, entomology, South Siberia, Mongolia.

КЛЮЧЕВЫЕ СЛОВА: фауна, COI, ITS2, энтомология, Южная Сибирь, Монголия.

ABSTRACT. When analyzing gene sequences COI and ITS2, we revealed minor differences (in COI) between the following taxa: Agriades orbitulus orbitulus (de Prunner, 1798), A. orbitulus pheretimus (Staudinger, 1892) and A. orbitulus jugnei Churkin, 2004, which confirms the subspecies status of these blues.

РЕЗЮМЕ. При анализе последовательностей генов COI и ITS2 были выявлены незначительные отличия по COI между таксонами: Agriades orbitulus orbitulus (de Prunner, 1798), A. orbitulus pheretimus (Staudinger, 1892) и A. orbitulus jugnei Churkin, 2004, что подтверждает их подвидовой статус.

\section{Introduction}

The Alpine Argus - Agriades orbitulus (de Prunner, 1798) — was described from Piemonte (Northern Italy). This is a rather widespread blue (Lepidoptera, Lycaenidae, Polyommatinae). Currently, it is indicated in Alps, Norway, Sweden, in several points of the Urals, in the mountains of South Siberia, the Lower Amur region, northern Sikhote-Alin, northeast China and Mongolia [Henriksen, Kreutzer, 1982; Gorbunov, 2001; Korshunov, 2002]. The subspecies structure is quite simple. The described later $A$. atys (Hübner, 1805) and A. pheretes (Hübner, 1805), both as Papilio, are synonyms of the nominative subspecies. From the Asian part of the habitat, three taxa of the subspecies level were described much later: Lycaena pheretes pheretimus Staudinger, 1892 (type locality: Kentei [Buryatia and Transbaicalian Regions, Malkhansky Mts.]), Lycaena pheretes sajana Heyne, [1895] (type locality Südliches Sibirien) and Albulina orbitulus jugnei Churkin, 2004 (type locality “ S. Mongolia, Gobi-Altai aimak, Tzakhir Khalgyn Nuruu, Detyin Davaa Pass). Some authors consider the above listed Asian taxa to be synonymous [Tshikolovets et al., 2009]. A point of view about the synonymy of pheretimus and sajana [Gorbunov, 2001] is also common. There is an opinion that pheretimus and sajana are bona subspecies [Zhdanko, 2000; Korshunov, 2002]. Chinese colleagues expressed the idea about the species status of Albulina sajana (Heyne, [1895]) [Wang, Fan, 2002]. The difficulty of analyzing the taxonomic situation is that the typical habitat of Lycaena pheretes sajana is completely unclear. In our opinion, the populations from Altai and Sayans are well distinguished from the Transbaikalian ones, see also images [Tuzov et al., 2000: plate 75]. But we can not clearly attribute the Altai and Sayan specimens with the taxon sajana up to specifying their typical

How to cite this article: Stradomsky B.V., Yakovlev R.V., Fomina E.S. 2019. Molecular genetic confirmation of the subspecies status of blues Agriades orbitulus pheretimus (Staudinger, 1892) and A. orbitulus jugnei Churkin, 2004 (Lepidoptera: Lycaenidae: Polyommatinae) // Russian Entomol. J. Vol.28. No.2. P.186 -188. doi: 10.15298/ rusentj.28.2.12 

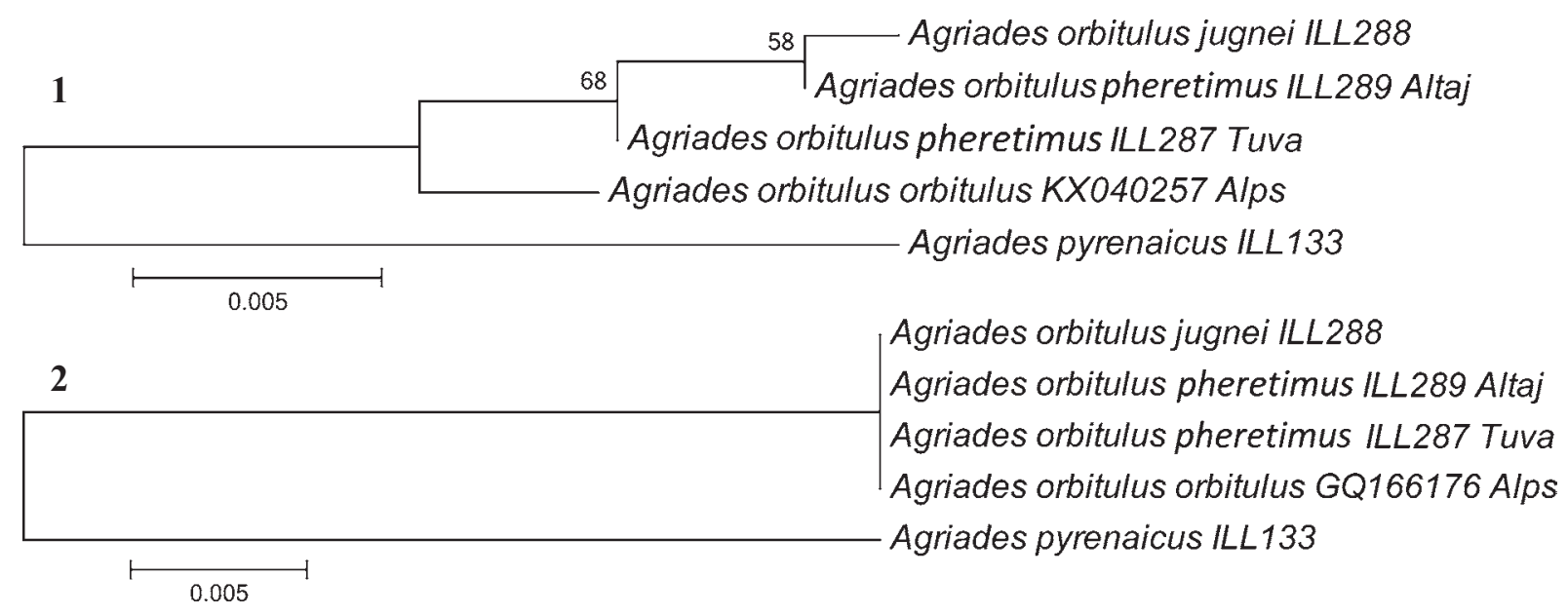

Figs 1-2. Agriades orbitulus ssp.: ML-cladogram for DNA sequences: 1 - COI; 2 - ITS2.

Рис. 1-2. Agriades orbitulus ssp.: ML-кладограмма для ДНК сиквенсов: 1 - COI; 2 - ITS2.

habitat, so currently we accept the point of view that Lycaena pheretes pheretimus Staudinger, $1892=$ ? Lycaena pheretes sajana Heyne, [1895]. Currently the genus Albulina is included in the genus Agriades [Talavera et al., 2013].

\section{Material and methods}

For molecular genetic studies, we used fresh material collected by a butterfly net in Russia (the Tuva Republic and the Altai Republic) and Mongolia (GobiAltai aimak): Agriades orbitulus pheretimus: $0^{7}$, Russia, Tuva, Kozhagar Mts., Kara-Sug vall., 1750 m, 5Jun-2017, R. Yakovlev (voucher ILL_287); $\sigma^{7}$, Russia, Altaj, Aktash, 7-Aug-2016, R. Yakovlev (voucher ILL 289); A. orbitulus jugnei: フ , Mongolia, GobiAltai aimak, near Dotijin-Davaa pass, 1950 m, 5-Jul2017, R. Yakovlev (voucher ILL_288).

We amplified DNA 5' section of the mitochondrial gene Cytochrome Oxidase subunit I (COI) and the nuclear noncoding sequence internal transcribed spacer 2 (ITS2) on the Mastercycler gradient (Eppendorf). The following cycling protocols were used: an initial $4 \mathrm{~min}$ denaturation at $95^{\circ} \mathrm{C}$ and 40 cycles of $30 \mathrm{~s}$ denaturation at $95^{\circ} \mathrm{C}, 30 \mathrm{~s}$ annealing at $53^{\circ} \mathrm{C}$ and $60 \mathrm{~s}$ extension at $72^{\circ} \mathrm{C}$. We used the following PCR primer pairs: forward, 5'-GTC AAC AAT CAT AAA ATA TTG G-3' with reverse, 5'-TTG CTC CAG CTA ATA CAG GTA A-3' were used to amplify COI. ITS2 was amplified with forward, 5'-GGG CCG GCT GTA TAA AAT CAT A-3' and reverse, 5'-AAA AAT TGA GGC AGA CGC GAT A-3’' [Stradomsky, 2016].

The amplified fragments were separated using an automated sequencing machine (Applied Biosystems 3500). The analysis of primary nucleotide sequences was made with the help of the application BioEdit Sequence Alignment Editor, version 7.0.5.3 [Hall, 1999]. COI and ITS2 nucleotide sequences were treated quantitatively using MEGA6 [Tamura et al., 2013] methods Maximum Likelihood (ML) and were represented as ML-cladograms.
Agriades pyrenaicus voucher ILL 133 (accession NoNo GenBank KC759734 (COI), KC759736 (ITS2)) was used as an outgroup to root the tree. Agriades orbitulus orbitulus (accession NoNo GenBank KX040257 (COI), GQ166176 (ITS2)) was used for comparison.

\section{Results and discussion}

The obtained results of molecular-genetic study are presented in the form of ML-cladograms of DNA sections for mitochondrial COI gene (Fig. 1) and nuclear sequence ITS2 (Fig. 2). The presented data suggest that mitochondrial DNA sequences in the examined specimens of $A$. orbitulus are very close to each other and differ only by $0.2-0.4 \%$, and from $A$. orbitulus orbitulus they differ by $0.7-1.1 \%$, which is characteristic only of the subspecies level.

All nuclear DNA sequences of ITS2 were generally identical to each other, which again speaks in favor of the species $A$. orbitulus unity.

Thus, molecular genetic characters demonstrate minor differences in the mitochondrial COI gene sequences of populations from the mountains of South Siberia (ssp. pheretimus =? sajana) and the Mongolian Altai highlands (ssp.jugnei) from the nominative subspecies, which indicates (in conjunction with the already known external differences) the subspecies status of these forms.

Acknowledgments. We express our gratitude to the colleagues for their assistance in the field studies on the territory of Mongolia (A. Fomichev, V. Rudoj, and A. Cherepanov). The authors are grateful to Anna Ustjuzhanina (Tomsk, Russia) for language improvements. The results were obtained within the framework of the state task No. 6.2884.2017/4.6 Ministry of Education and Science of Russian Federation.

\section{References}

Gorbunov P.Y. 2001. [The butterflies of Russia: classification, genitalia, keys for identification (Lepidoptera: Hesperioidea and Papilionoidea)]. Ekaterinburg: Thesis. 320 p. [In Russian] 
Hall T.A. 1999. BioEdit: a user-friendly biological sequence alignment editor and analysis program for Windows 95/98/NT // Nucleic Acids Symposium Series. Vol.41. P.95-98.

Henriksen H.J., Kreutzer I. 1982. The Butterflies of Scandinavia in Nature. Odense: Skadinavisk Bogforlag. 215 pp.

Korshunov Y.P. 2002. [Butterflies of Northern Asia]. Moscow: KMK Sci. Press. 424 p. [In Russian]

Stradomsky B.V. 2016. A molecular phylogeny of the subfamily Polyommatinae // Caucasian entomological bulletin. Vol.12. No.1. P.145-156.

Talavera G., Lukthanov V.A., Pierce N.E., Vila R. 2013. Establishing criteria for higher level taxonomic classification using molecular data: the systematics of Polyommatus blue butterflies (Lepidoptera, Lycaenidae) // Cladistics. Vol.29. P.166-192.
Tamura K., Stecher G., Peterson D., Filipski A., Kumar S. 2013. MEGA6: Molecular Evolutionary Genetics Analysis Version 6.0 // Molecular Biology and Evolution. Vol.30. No.12. P.27252729. DOI: $10.1093 / \mathrm{molbev} / \mathrm{mst} 197$.

Tshikolovets V.V., Yakovlev R.V., Balint Z. 2009. The Butterflies of Mongolia. Kyiv-Pardubice: Tshikolovets-Press. 320 pp.

Tuzov V.K., Bogdanov P.V., Churkin S.V., Dantchenko A.V., Devyatkin A.L., Murzin V.S., Samodurov G.D., Zhdanko A.B. 2000. Guide to the Butterflies of Russia and adjacent territories (Lepidoptera, Rhopalocera). Sofia: Pensoft. Vol.2. 580 pp.

Wang M., Fan X. 2002. Butterflies Fauna Sinica: Lycaenidae. Zhengzhou: Henan Science and Rechnology Publishing House. $440 \mathrm{pp}$.

Zhdanko A.B. 2000. Genus Albulina. // Tuzov V.K. et al. Guide to the Butterflies of Russia and adjacent territories (Lepidoptera, Rhopalocera). Sofia: Pensoft. Vol.2. P.183-184. 